2. Контекстуальная конкретизация, вызванная стилистическими соображениями, стремлением избежать ненужных повторений;

3. Компенсация, при которой элементы текста оригинала, содержащие определенную информацию, передаются другими средствами в языке перевода;

4. Добавления;

5. Опущения слов, которые при переводе становятся семантически избыточными.

Список литературы:

1. Алексеева И.С. Профессиональный тренинг переводчика / И.С. Алексеева: учеб, пособие. СПб.: СОЮЗ, 2001.
2. Бархударов Л.С. Язык и перевод (Вопросы общей и частной теории перевода) / Л.С. Бархударов. - М.: «Международные отношения», 1975.

3. Дурнева, К.А. Лексико-грамматические особенности перевода договоров и контрактов с английского языка на русский / К.А. Дурнева // Вестник Кемеровского государственного университета. -2014. № 4 (60). С. 155 - 160 .

4. Киндеркнехт, А.С. Особенности перевода юридических текстов / А.С. Киндеркнехт // Ученые записки Орловского государственного университета. Серия: гуманитарные и социальные науки. 2015. № 5 (68). Орел: Изд-во Орловск. гос. ун-та. С. $123-127$.

\title{
THE ROLE OF FOLKLORE SAMPLES IN STYLISTIC DEVICES OF NOVELS
}

(As the sample in "Makhmud Tarabiy" of Asad Dilmurad)

\author{
Kurbanbaeva Nasiba \\ 1 st year Master student \\ Literary criticism: Literature of Uzbek Literature
}

\section{РОЛЬ ФОЛЬКЛОРНЫХ ОБРАЗЦОВ В СТИЛИСТИЧЕСКИХ УСТРОЙСТВАХ РОМАНОВ}

(Как образец в «Махмуд Тарабий» Асада Дилмурада)

\section{Курбанбаева Насиба \\ Студент 1 курса магистратуры \\ Литературная критика: литература узбекской литературы DOI: 10.31618/ESU.2413-9335.2019.7.63.189}

\section{RESUME}

The article features the peculiarities of Asad Dilmurod's novel Mahmud Torobiy, in particular his views on the role of the work in the Uzbek literature. The role of the folklore samples in the novel art texture was studied by the example of Asad Dilmurod's creativity.

Key words: folklore, novel, literature, literary

In the 20th century, dozens of novels are devoted to the national spirit and heroic interpretation of the $\mathrm{Uz}$ bek literature, many of which reflect national traditions and folkloric traditions of folklore. The national spirit is formed in the context of certain ethnic ethno-cultural traditions, the customs of the people, ceremonies and oral art are the main components of this national environment.In order to speak about the artistic-aesthetic interpretation of the national spirit and to come to certain scientific conclusions, it is necessary to study the nature of the nation, the spiritual values and traditions which are the basis of the national character, in the Uzbek novel of independence. It is one of the most important aspects of today's literary process, because the artistic perception of national values and traditions, as well as the creation of "national identity", expressed in ceremonies and festivals, are also among the most important features of today's literary process. The use of folklore in literary literature is a tradition that has long been an artistic principle. Folklore has always been an artistic and aesthetic foundation that enriches the content and content of written literature and continually improves its poetic potential. In the formation and development of written literature, oral genres play an important role as an artistic foundation. Each literary literature deals with national values based on their artistic-aesthetic needs and the level of artistic requirements.
In other words, the attitude of folklore and written literature is one of the most consistent artistic aesthetic traditions that have survived to the present day.

In addition to the effective use of the folklore epic polemics, the artistic expression of the story tells about the cosmogonic views of our people about the three worlds - the sky, the earth and the earth, and the animated myths about the journey of the soul to another world. It is, especially, evident in the mythological images associated with the dream motif in the analysis, and it helps to clarify the creator's artistic skills.

It is known that the motive of the dream is one of the traditional elements of the Uzbek folklore poetic creativity, and three times of the motive, reality or character of the behavior of the characters are reflected in the epic poetry. Because "these traditional trials lead to the next adventure and make it fun".

It is well known that in the world folklore, there is a practice of verbal interpretation within the mythological sections. The well-known scientist Z. Freud, who founded the direction called "the theory of spiritual analysis" in mythology,and his followers studied the origin of ancient myths with the primitive human nature's unconscious emotional relationships. They have come to the conclusion that the dream is interpreted by dream, and by dream symbols, as in myths. Hence, in the written prose, the motives of the dream are widely used to describe the mood and experiences of the hero. 
Dreams are a phenomenon that is directly related to the human spirit, and various psychological states, such as dreams, fears and anxiety, which are occupied by a person's mind, activate his perceptive senses while sleeping and create a system of information that can be expressed through certain symbols. Such symbolic information is what happens in the life of a human being in the form of a symbolic expression of events or a form of dreams. The writer also uses artistic details as part of the dream, in light of his creative intentions, to relate events and to illuminate the mood of the hero.

The artistic interpretations related to the dream come true in the historical novel "Mahmud Torobiy", by Asad Dilmurod. Mahmud Torobiy, who came to the palace in the form of a skeleton, addresses the governor of Khujand, Mahmud Yalavoch, "Have you seen a dream?" The governor is surprised at this. Indeed, the governor, who really made the night frenzy, had a dream. In the dream, the black hawk flew down, and Mahmud pointed to Yalawake with his shoulders and sailed to Sumerian Mountain, where he could go to the underground country. Then there is a voice from the unseen: "Stare, hey, man!" "O Lord, where are you going to be poor?" He asked trembling. The voice in the uncertainty threatened: "The Lord is alien to you, forget him!" It was as if he had been wounded in his throat: "What is that?" The sharp voice of the noise was heard:

"You are out of either paradise orhell, you are condemned to a land under the dominion of the earth."

After that, the hero is going to pass through a hard test.If they want to drink water when they are thirsty or eat fruit from the garden, they will disappear or become rock. Thousands of years passed before a certain hut, they met Chingiz Khan and his wife Burta. While Chingiz is looking after sheep and his wife is cooking her wife, it is very cold and they are accused of treason, betraying their fellow countrymen. He remains in the hands of the so-called Ulgen and the Land.As it is known, the ancient Turkic mythology is the ruler of the earthly evil, and Ulgen is god of goodness. Hence, the Ulgen and the Earth are two symbols of two different powers. "The universe is a balance of good and evil forces. This struggle is reflected in a person's spirit. If there is evil in man's mental state, then the god of evil will enter into him, and imagine that he will only make man do bad things. "

In the ancient Turkish myths, the Great World created the universe on the ocean. Ulman, who sails in Oman, has created the earth with the advice of his mother, White Ene, and with his direct involvement all the plants and animals on the ground. In this way, he was the landlord of the great light.The underworld is given the power of evil, which is called Earth. So the earthly creature asked for a stake from the earth to give it its rightful place, and when it had been given to it, he plucked the earth with his own stick, and so forth, the world of darkness - creatures, scorpions, which made the earth beneath.

Hence, Asad Dilmurod is trying to create his own imagination in the context of good and evil, by performing his literary intentions by introducing the mythological images of the ancient Turkic folklore folklore. He also uses a dream motto to introduce folklorism to the subject of the art. Through the reality described in the dream, not only the hero of the art, but also the reader, also warns of the tragedies of evil and the world. In the dream, Chingiz Khan, who trembles with the world, is taking his actions, not the wealth he has accumulated in the world. Those who are frozen in the desert will inherit their evil. Even though the long-lasting advice of Jung has affected the ruler who wakes up from sleep, he does not make the right conclusion. However, the writer uses the dream motif as a kind of poetic instrument to explore the spirit realm of his hero and to increase the sensitivity of the artistic interpretation.

To do this, he is referring to mythological logic, which is often seen in fairy tales, a land that leads to it, a bird that flies over an epic hero (mediator between the two worlds), and black holes. It is not surprising that in the novel, the bird's image was flying. Because in the Uzbek folk tales Semurg's image, which performs the same function, is widely depicted. "Semurg is the embodiment of totemic sponsorship, a great bird that is a supporter of fortune-tellers, according to the primitive understanding of our ancient ancestors. It is difficult to say when this beautiful lyric picture appeared, but ancient stories about Semurg are common in the Oriental folklore. He is able to carry the hero to the great wing, to take him to the underworld or to bring it out to the ground. "The novel "Mahmud Torobiy" is one of the works that reflects the specificity of the process of reproduction of the artistic image of the Uzbek prose. Through this work, author tells the story of the world of his superficial thinking to heroism and tells about the impact of the social environment on human life.

\section{References:}

1. Ethnos and culture: Tradition and modernity. Tashkent: Science, 2010.

2. AsadDilmurod. Mahmud Tarabiy. - Tashkent: East, 1998. - B.135.

3. Uzbek folklore poetic creativity. - Tashkent: Teacher, 1980. - B.147.

Freud Z. Totem and Taboo. Per. s moisture. - M., 1923.

5. Eshonqul J. Myth and novel // Literature and art of Uzbekistan. - Tashkent, 1997. - April 25.

6. Juraev M., Narzikulova M. Myth, folklore and literature. - Tashkent: Publisher of the National Library of Uzbekistan, 2006. - B.68 